Ethos : Jurnal Penelitian dan Pengabdian kepada Masyarakat, Vol 7, No.2, Juni 2019: 210-223

\title{
LINTAS-BD 1.1: MODEL DAN SIMULASI LALU LINTAS KOTA BANDUNG
}

\section{${ }^{1}$ Erwin Harahap, ${ }^{2}$ Farid Badruzzaman, ${ }^{2}$ Yurika Permanasari, ${ }^{2} \mathrm{M}$ Yusuf Fajar, ${ }^{2}$ Abdul Kudus}

\author{
${ }^{1,2)}$ Universitas Islam Bandung, Bandung, Jawa Barat, Indonesia \\ E-mail: 1,2) erwin2h@unisba.ac.id
}

\begin{abstract}
Traffic is a vital for land transport that connects various locations and even large cities. As civilization and population grew, traffic became more congested and resulted in congestion, a problem that can not be avoided. One solution that has been carried out by the government to overcome this problem is by applying traffic management and methods. Nevertheless, the right method without careful planning can cause nonoptimal results, besides the amount of expenditure spent in the form of costs, time, thoughts, and energy. In this study, researchers compile a traffic simulator system called "LINTAS" which serves as a tool to solve traffic congestion problems. Various methods and management designs, before they are actually implemented on the highway, can be simulated first through the LINTAS system. The benefit of LINTAS system is to test and simulate traffic conditions based on a particular method or management design. Through this simulation, the most appropriate traffic management method is expected to be found to overcome traffic congestion problem. The LINTAS simulator is compiled using the SimEvents toolbox and runs on the MATLAB-Simulink software. The LINTAS system simulation method is made based on Mathematics, specifically the Queuing Theory.

Keywords: Traffic, Congestion, Simulation, the Queuing Theory, SimEventsMatlab
\end{abstract}

\begin{abstract}
Abstrak. Lalu lintas adalah sarana penting media transportasi yang digunakan untuk perjalanan dari satu lokasi ke lokasi lainnya. Kelancaran sistem lalu lintas adalah parameter dari perkembangan suatu kota atau daerah, yang meliputi perkembangan ekonomi, sosial, pendidikan, teknologi, dan lain-lain. Dengan bertambahnya penduduk, maka jalan raya menjadi padat dan menimbulkan antrian panjang. Solusi umum yang dilakukan adalah dengan memperluas kapasitas jalan. Namun, secara umum solusi ini kurang signifikan karena memerlukan biaya yang cukup besar serta mekanisme pembebasan tanah yang cukup sulit. Dalam penelitian ini, diusulkan sebuah metode untuk mengurangi kemacetan lalu lintas melalui simulasi dengan menggunakan aplikasi "LINTAS-BD 1.1". Aplikasi ini berfungsi untuk mensimulasikan suatu rekayasa atau metode pengalihan jalur lalu lintas sebelum diterapkan secara nyata. Metode simulasi ini dilakukan untuk mengevaluasi kondisi dan situasi lalu lintas dengan berdasarkan penerapan rekayasa atau metode tertentu. Melalui metode simulasi ini diharapkan dapat diperoleh dan dievaluasi secara analitis mengenai akurasi, efektifitas, dan efisiensi, dari metode dan rancangan suatu rekayasa lalu lintas. Penelitian ini bertujuan untuk menyusun sebuah aplikasi yang dapat digunakan sebagai sebuah media untuk memperkirakan, menganalisis, digunakan sebagai alat uji coba metode atau rekayasa pada lalu lintas.
\end{abstract}

Kata kunci: lalu-lintas, kemacetan, simulasi, teori-antrian, simevents-matlab 


\section{Pendahuluan}

Kepadatan transportasi semakin meningkat seiring dengan waktu, dimana ditandai dengan bertambahnya jumlah kendaraan terus menerus melampaui kapasitas jalan raya. Hal ini yang akhirnya mengakibatkan kemacetan lalu lintas (Ariyanti. 2017). Kemacetan timbul akibat terhambatnya pergerakan kendaraan yang umumnya disebabkan karena dua alasan, yaitu pertama adalah kapasitas jalan yang tidak memadai, atau kedua adalah karena terlalu banyaknya jumlah kendaraan (Prakarsa. 2017). Salah satu pemecahan permasalahan ini adalah dengan peningkatan meningkatkan kapasitas jalan (Halim. 2017) Namun peningkatan kapasitas membutuhkan dana pembangunan yang sangat mahal. Dilain pihak, pengurangan jumlah kendaraan juga tidak sederhana, karena berkaitan dengan regulasi pemerintah serta aktifitas masyarakat sehari-hari. Kemacetan terjadi diberbagai lokasi karena jumlah penduduknya yang padat dan sibuk. Kemacetan juga dapat terjadi karena kurang baiknya pengaturan lalu lintas, dan tingkat kedisiplinan pengguna lalu lintas yang rendah (Ravel. 2016).

Kemacetan lalu lintas harus diatasi karena sangat merugikan masyarakat, diantaranya adalah kerugian waktu perjalanan, bahan bakar boros, panas mesin yang berlebihan, polusi udara, stress, dan lain-lain (Retaduari. 2017). Kerugian lain dari kemacetan adalah kelancaran transportasi darurat terganggu, seperti ambulans dan pemadam kebakaran (Rachman. 2015). Pemerintah kota Bandung, telah menerapkan beberapa metode untuk mengatasi kemacetan lalu lintas Namun pada kenyataannya kemacetan masih banyak terjadi diberbagai lokasi. Hai ini menunjukkan bahwa rekayasa lalu lintas di kota Bandung untuk mengatasi kemacetan belum optimal (Agustina. 2017). Situasi ini mungkin disebabkan oleh metode rekayasa lalu lintas yang belum tepat. Oleh sebab itu, sangat diperlukan sebuah sistem aplikasi yang dapat memperkirakan keadaan lalu lintas pra dan pasca diterapkannya rekayasa lalu lintas.

Dalam artikel ini, penulis mengajukan sebuah aplikasi untuk mensimulasikan situasi lalu lintas yang dinamakan "LINTAS 1.1" yang merupakan pengembangan dari rancangan sistem sebelumnya (Ispranoto. 2017). Aplikasi LINTAS adalah sebuah software yang berlandaskan pada ilmu Matematika, model-model antrian dan beberapa teori peluang (Bolch, dkk. 2006). Aplikasi LINTAS diharapkan dapat berfungsi sebagai pendukung bagi pengelola lalu lintas untuk dapat meningkatkan efektifitas dalam menerapkan metode atau rekayasa lalu lintas sebelum diterapkan di jalan raya, sehingga kemacetan dapat dihindarkan.

Aplikasi LINTAS disusun menggunakan teknologi terbaru berbasis model, tidak menggunakan coding yang rentan error. Melalui teknologi berbasis model, LINTAS dibangun dengan menghubungkan berbagai blok modul hingga membentuk sistem aplikasi yang terintegrasi. LINTAS disusun sebagaimana sebuah puzzle, sehingga menyederhanakan para peneliti untuk melakukan pengembangan sistem. Aplikasi LINTAS dapat dikembangkan untuk meningkatkan fungsinya dalam memperkirakan situasi jalan raya secara akurat, dan mensimulasikan metode atau rekayasa sebelum diterapkan. Selain itu, aplikasi LINTAS juga dapat memperkirakan pengaruh jangka waktu 
pada lampu lalu lintas terhadap jumlah antrian kendaraan, menganalisis pengaruh kendaraan yang parkir di tepi jalan terhadap terjadinya kemacetan, mengevaluasi ketidakteraturan kendaraan angkutan umum terhadap kemacetan lalu lintas, menyelidiki dan memperkirakan faktor-faktor penyebab timbulnya kemacetan, serta menemukan solusi untuk mengatasi kemacetan diberbagai lokasi demi terciptanya lalu lintas yang tertib, aman, dan lancar.

Kemacetan lalu lintas merupakan salah satu masalah di kota Bandung yang harus segera dilakukan langkah penyelesaiannya. Pemerintah kota Bandung sangat serius untuk mengatasi permasalahan kemacetan ini, dimana ditunjukkan dengan telah dilaksanakannya proyek-proyek besar dalam upaya memecahkan masalah (Harahap, dkk. 2013). Pelebaran jalan raya di kota Bandung kecil kemungkinannya untuk dilakukan, sementara jumlah kendaraan tiap tahun terus meningkat. Apabila tidak dilakukan usaha penyelesaian, maka permasalahan kemacetan di kota Bandung akan terus berkembang dan menjadi polemik yang berkepanjangan.

\section{Landasan Teoritis}

\section{LINTAS: State of the art}

Kemacetan lalu lintas menjadi masalah utama diberbagai kota di Indonesia. Kemacetan jalan raya Kota Bandung dapat ditemui pada hampir di sebagian besar lokasi jalan pada jam-jam sibuk. Untuk menganalisis dan mengevaluasi kemacetan jalan raya diperlukan pengetahuan dan pemahaman mengenai Rekayasa Lalu Lintas. Situasi lalu lintas Seiring waktu dari tahun ke tahun semakin padat dan kompleks, sehingga sering menimbulkan permasalahan baru disamping kemacetan. Oleh karena itu, dalam merencanakan sistem lalu lintas dibutuhkan kajian atas dampak yang akan terjadi di masa yang akan datang.

Aplikasi LINTAS adalah sebuah sistem yang dirancang untuk menjalankan simulasi lalu lintas dengan berdasarkan pada ilmu model-model antrian. LINTAS dibangun untuk melakukan simulasi dengan beberapa parameter input, diantaranya adalah kapasitas jalan raya, rata-rata laju kedatangan kendaraan, rata-rata laju waktu menunggu kendaraan dalam suatu kondisi tertentu misalnya dalam antrian kemacetan, antrian lampu lalu lintas, atau pada pintu kereta, dan parameter lainnya. Berdasarkan input tersebut, LINTAS dapat memperkirakan tingkat kemacetan yang mungkin akan terjadi, panjang antrian, jumlah kendaraan, jangka waktu perjalanan dari mulai awal hingga tujuan, dan perkiraan lainnya yang mungkin dibutuhkan untuk bahan evaluasi manajemen lalu lintas.

Selain mengolah berbagai parameter diatas, LINTAS disusun untuk dapat memperkirakan kondisi lalu lintas setelah diterapkannya suatu metode atau rekayasa. Sebagai contoh, perubahan arah kendaraan menjadi satu jalur atau dua jalur, pengalihan rute kendaraan secara dinamis, penyeimbangan arus kendaraan (load balancing), rekayasa lampu persimpangan lalu lintas (Harahap, dkk. 2017). serta metode atau rekayasa lainnya yang dapat diterapkan pada aplikasi LINTAS. Simulasi lalu lintas diharapkan dapat membantu para pengelola lalu lintas untuk menemukan metode atau rekayasa yang tepat sehingga menciptakan situasi lalu lintas yang lancar dan terhindar dari kemacetan.

LINTAS 1.1 merupakan peningkatan dari sistem LINTAS sebelumnya yang dikembangkan sejak 
tahun 2018 dengan spesifikasi sebagai berikut:

a) Model-based Disain. LINTAS disusun menggunakan software MATLAB-Simulink, SimEvents Toolbox [26]. LINTAS dibangun melalui susunan modul-modul. Metode model-based relatif lebih sederhana dibandingkan dengan metode coding, sehingga peneliti lebih fokus pada disain sistem aplikasi, tidak terganggu oleh error karena salah coding.

b) Universal. Banyak media masukkan dan keluaran dapat dihubungkan dengan aplikasi LINTAS. Media masukkan diantaranya: data online, CCTV, dan berbagai tipe sensor masukkan. Untuk media keluaran antara lain: monitor, website, serta data yang dapat digunakan oleh user.

c) Customize-able. Aplikasi LINTAS dapat disesuaikan untuk menerapkan suatu metode atau rekayasa tertentu, dan kemudian disimulasikan untuk memperkirakan hasilnya pada situasi lalu lintas.

d) Accessible. Aplikasi LINTAS dimungkinkan untuk dapat dipasang pada teknologi server atau cloud sehingga diakses diakses oleh masyarakat yang membutuhkan.

e) Friendliness Output. Keluaran dari aplikasi LINTAS dapat berupa data grafik atau data time series yang dapat digunakan untuk penelitian, pengamatan, atau evaluasi lebih lanjut.

Pengembangan pada LINTAS 1.1diantaranya adalah area simulasi yang lebih luas.

\section{Penelitian Terkait}

Disain simulasi dan pemodelan mengenai alur lalu lintas telah banyak dilakukan oleh para peneliti.
Diantaranya adalah pemodelan arus lalu lintas menggunakan persamaan kinematic, pemodelan arus lalu lintas roundabout , dan sistem simulasi untuk lalu lintas secara parsial atau spesifik pada kasus tertentu (Harahap, dkk. 2016) yang khusus mensimulasikan tentang persimpangan jalan. Terdapat juga peneliti lainnya yang melakukan kajian lalu lintas secara parsial, hanya mengenai pengaruh pejalan kaki, keramaian pasar atau terminal terhadap kemacetan lalu lintas.

Aplikasi LINTAS mulai diperkenalkan pada Maret 2018 (Wijekoon, 2014). Pada penelitian ini, metode simulasi terus dikembangkan dengan dasar ilmu teori antrian. Hasil dari penelitian ini adalah diharapkan metode simulasi dapat memberikan visualisasi atau gambaran yang cukup jelas tentang kondisi lalu lintas sebelum dan sesudah diterapkannya suatu rekayasa.

\section{Rancangan Sistem Simulasi}

Aplikasi LINTAS disusun menggunakan toolbox SimEvents, MATLAB-Simulink (Fadhillah, dkk. 2017) . Aplikasi ini mirip dengan aplikasi simulasi CDNlink (Harahap, dkk. 2010) dimana perbedaannya yang tampak adalah pada penerapannya yang lebih fokus pada simulasi sistem jaringan komputer atau Internet. Aplikasi simulasi LINTAS dibangun dengan menyusun berbagai blok modul yang ditunjukkan pada gambar 1 .

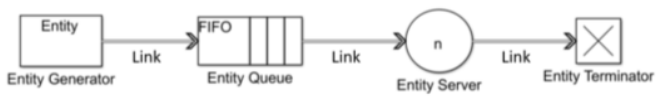

Gambar 1. Rancangan Sistem Dasar Simulator LINTAS 
Sesuai pada Gambar 2.1, aplikasi LINTAS secara umum dibuat dalam lima blok modul utama yaitu, generator, link, queue, server, dan terminator. Modul generator memiliki fungsi sebagai pembangkit data, dimana titik awal kedatangan kendaraan dihitung berdasarkan pada banyaknya kedatangan kendaraan per satuan waktu. Modul Link memiliki fungsi sebagai jalan raya dimana kendaraan bergerak. Kapasitas modul link dapat diatur ukurannya sesuai dengan situasi lalu lintas jalan raya, satu jalur, dua jalur atau lebih, namun hanya bisa digunakan sebagai jalan satu arah. Untuk disusun sebagai arus lalu lintas dua arah, harus dibuat modul link masing-masing.

Modul Queue berfungsi sebagai blok antrian kendaraan. Pada saat suatu kendaraan diproses, kendaraan lainnya akan melakukan antrian dan ditempatkan pada modul queue. Modul Server memiliki sebagai pelaksana proses layanan kendaraan. Proses layanan ini adalah misalnya pada saat kendaraan terhambat atau berhenti dikarenakan suatu kendala dalam satu satuan waktu. Modul Terminator, memiliki fungsi sebagai akhir arus kendaraan. Kendaraan yang tiba pada modul ini selanjutnya dihapus atau tidak dipergunakan kembali

\section{Teori Antrian}

Aplikasi LINTAS beroperasi berdasarkan kepada model-model antrian. Teori antrian banyak digunakan dalam evaluasi dan analisis lalu lintas untuk memantau kemacetan melalui berbagai parameter, antara lain rata-rata laju kedatangan kendaraan, panjang antrian kendaraan, waktu menunggu dalam antrian, dan lain-lain.

Beberapa teori dasar model antrian yang digunakan pada aplikasi LINTAS adalah rata-rata laju kedatangan $(\lambda)$, yaitu rata-rata laju kedatangan kendaraan yang masuk ke dalam sistem simulasi per satu satuan waktu. Rata-rata laju waktu proses atau waktu pelayanan dalam sistem $(\mu)$ adalah rata-rata laju waktu pelayanan kendaraan selesai di proses dan keluar selesai dari sistem lalu lintas per satu satuan waktu. Pada artikel ini diasumsikan model antrian yang diterapkan adalah $\mathrm{M} / \mathrm{M} / n$ dimana $n$ adalah jumlah layanan ditunjukkan dalam bilangan asli. Pada model M/M/n, kedatangan kendaraan diasumsikan bersifat Poisson dengan laju waktu pelayanan mengikuti distribusi eksponensial.

Berdasarkan kepada model antrian $\mathrm{M} / \mathrm{M} / \mathrm{n}$, rata-rata panjang antrian (L) pada kondisi stabil atau steady-state dihitung berdasarkan pada rumus berikut:

$$
\mathrm{L}=\frac{\mathrm{P}_{0}(\lambda-\mu)^{\mathrm{n}} \lambda / \mathrm{n} \mu}{\mathrm{n} !(1-\lambda / \mathrm{n} \mu)^{2}}
$$

dimana

$\left.\frac{(\lambda / \mu)^{i}}{i !(1-\lambda / n \mu)}\right]^{-1}$

$P_{0}=\left[\sum_{i=0}^{n-1} \frac{(\lambda / \mu)^{i}}{i !}+\right.$

Rumus panjang antrian (1) sudah tergabung didalam modul Queue pada aplikasi LINTAS. Hasil dari kalkulasi panjang antrian berdasarkan modul Queue untuk simulasi dengan waktu tak terhingga, memberikan nilai hasil konvergen dengan menggunakan rumus (1). Selanjutnya, tingkat utilitas atau kepadatan lalu lintas $(\rho)$ dihitung berdasarkan pada rumus berikut:

$$
\rho=\frac{\lambda}{\mu}
$$


dimana rata-rata laju waktu pelayanan atau proses adalah $1 / \mu$. Sebagaimana pada panjang antrian $(L)$, perhitungan tingkat utilitas atau kepadatan lalu lintas $(\rho)$ juga sudah tergabung pada modul Server.

Sistem antrian dapat digambarkan sebagai kedatangan kendaraan yang kemudian melakukan antrian karena adanya hambatan dan selanjutnya meninggalkan antrian. Pola kedatangan merupakan salah satu komponen dasar dalam model antrian. Pola kedatangan entiti atau kendaraan dalam hal ini dapat dipandang dari sisi waktu antar kedatangan pada dua kendaraan yang berurutan (interarrival time) yang secara umum dapat bersifat deterministik atau stokastik. Pola kedatangan kendaraan dikatakan deterministik jika waktu antar kedatangan dua kendaraan adalah tetap atau tidak berubah, sehingga waktu kedatangan antar kendaraan dapat ditentukan. Laju kedatangan deterministik menghasilkan panjang antrian tetap. Pola kedatangan yang lainnya adalah pola stokastik, dimana waktu antar kedatangan kendaraan tidak tetap dan dapat dihitung dengan menggunakan suatu rumus dan distribusi tertentu.

Pelayanan (server) pada sistem antrian untuk jumlah layanan dapat dikelompokkan pada dua kategori, yaitu pelayanan tunggal dan jamak. Banyaknya jumlah layanan disesuaikan dengan banyaknya kedatangan kendaraan. Sebagai contoh adalah antrian kendaraan pada gerbang pintu jalan tol. Apabila jumlah kedatangan kendaraan rendah, maka cukup menggunakan satu pintu layanan. Namun jika terjadi kedatangan kendaraan yang cukup tinggi, maka agar tidak terjadi antrian panjang, pintu gerbang tol harus bekerja lebih cepat. Akan tetapi, jika kecepatan layanan terbatas pada nilai rata-rata tertentu, maka untuk menghindari terjadinya antrian kendaraan, dapat ditambahkan pintu layanan disesuaikan dengan jumlah kedatangan kendaraan.

Pada penelitian ini digunakan model antrian $\mathrm{M} / \mathrm{M} / 1$, yaitu sistem antrian Markov dimana kedatangan dan layanan kendaraan dikatakan stabil dengan rata-rata tertentu. Kedatangan kendaraan diasumsikan mengikuti proses Poisson, waktu layanan diasumsikan mengikuti distribusi eksponensial, dan diasumsikan menggunakan layanan tunggal. Karakteristik dari sistem antrian Markov adalah ergodic, yaitu akan memiliki karakteristik yang sama pada rent ang waktu yang cukup panjang, dan sistem antrian berada pada kondisi steady state. Kedatangan kendaraan dilambangkan dengan variabel $\lambda$, dan layanan adalah $\mu$.

Pada model $\mathrm{M} / \mathrm{M} / 1$, rata-rata jumlah kendaraan $(\mathrm{N})$ didalam sistem dirumuskan sebagai

$$
\mathrm{N}=\frac{\rho}{1-\rho}=\frac{\lambda}{\mu-\lambda}
$$

dimana $\rho$ adalah utilization atau tingkat kepadatan kendaraan dengan rentang nilai diantara 0 dan 1 . Untuk model $\mathrm{M} / \mathrm{M} / 1$, nilai $\rho$ harus kurang dari 1. Rata-rata kendaraan menunggu dalam sistem (T) dirumuskan sebagai

$$
\mathrm{T}=\frac{\mathrm{N}}{\lambda}=\frac{1}{\mu-\lambda}
$$


Rata-rata waktu tunggu dalam antrian (W) dirumuskan dengan

$$
\mathrm{T}=\mathrm{W}-\frac{1}{\mu}=\frac{\rho}{\mu-\lambda}
$$

dan rata-rata jumlah kendaraan didalam antrian $\left(\mathrm{N}_{\mathrm{q}}\right)$ dirumuskan dengan

$$
\mathrm{N}_{\mathrm{q}}=\mathrm{W}-\frac{1}{\mu}=\frac{\rho}{\mu-\lambda}
$$

\section{Metode Penelitian}

\section{Pengumpulan Data}

Data yang akan dibahas pada artikel ini adalah diperoleh melalui observasi di lapangan, tepatnya di beberapa lokasi/jalur lalu lintas kota bandung. Data durasi lampu lalu lintas satu siklus diambil dari empat ruas jalan suatu perempatan. Durasi lampu merah dan lampu hijau diperoleh dalam satuan waktu detik. Dalam penelitian ini, lampu kuning diperhitungkan sebagai lampu hijau karena sifatnya sebagai $p$

terhadap perubahan warna, dan juga karena pada saat lampu kuning, kendaraan tetap bergerak hingga menyala lampu merah. Variabel lainnya yang dikumpulkan adalah kedatangan kendaraan, banyak kendaraan dalam antrian, dan banyaknya kendaraan yang keluar dari keempat ruas jalan.

\section{Metode Penelitian}

Langkah-langkah pelaksanaan penelitian diuraikan berdasarkan pada diagram alir pada Gambar 2.

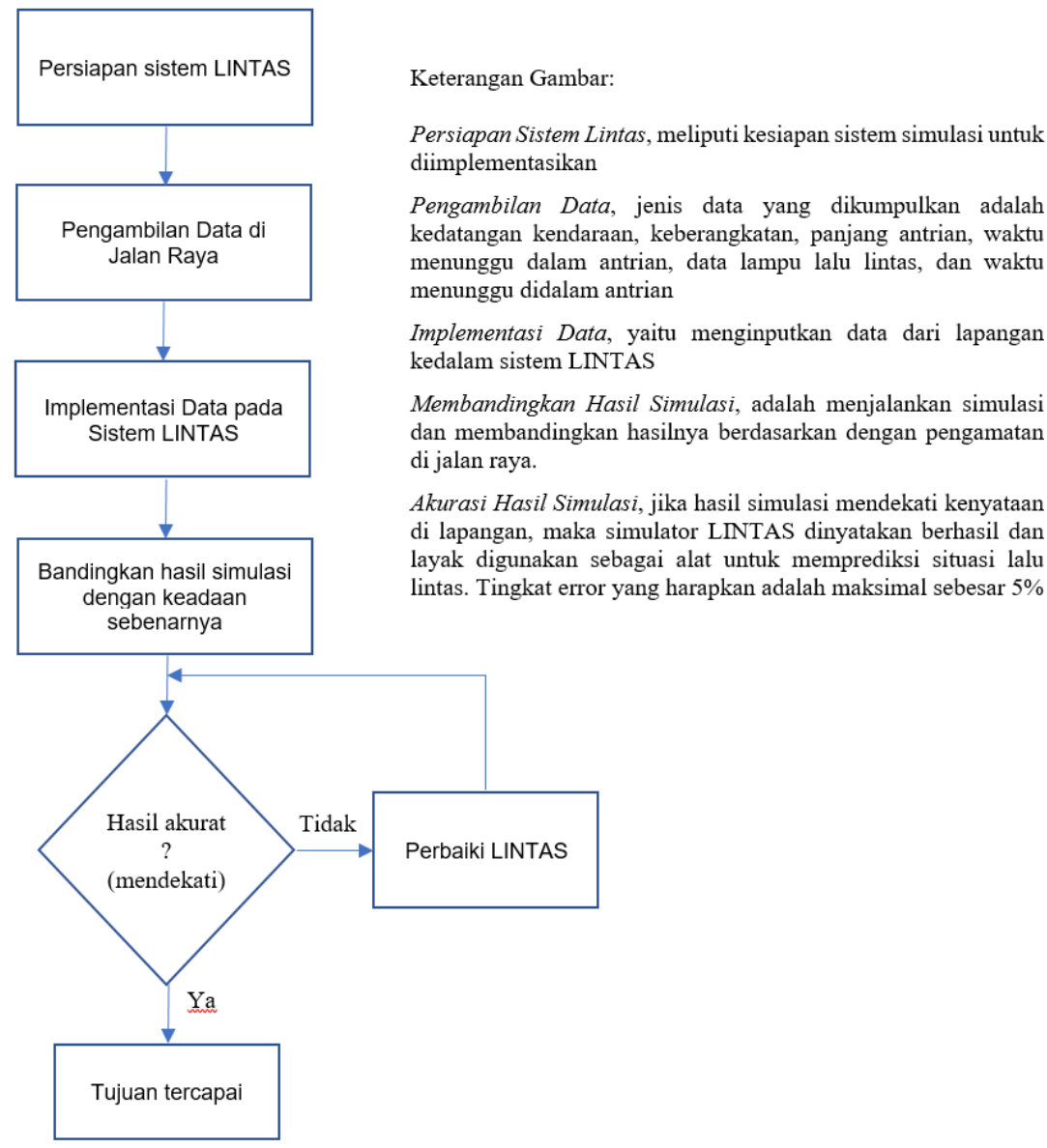

Gambar 2. Tahapan Penelitian Disain dan Model Sistem LINTAS 


\section{Hasil dan Pembahasan}

Data yang akan dibahas pada artikel ini adalah diperoleh melalui observasi di lapangan, tepatnya di beberapa lokasi/jalur lalu lintas kota bandung. Data durasi lampu lalu lintas satu siklus diambil dari empat ruas jalan suatu perempatan. Durasi lampu merah dan lampu hijau diperoleh dalam satuan waktu detik. Dalam penelitian ini, lampu kuning diperhitungkan sebagai lampu hijau karena sifatnya sebagai peringatan terhadap perubahan warna, dan juga karena pada saat lampu kuning, kendaraan tetap bergerak hingga menyala lampu merah. Variabel lainnya yang dikumpulkan adalah kedatangan kendaraan, banyak kendaraan dalam antrian, dan banyaknya kendaraan yang keluar dari keempat ruas jalan.

Implementasi dari simulator lalu lintas tertentu di kota Bandung. Sistem LINTAS yang akan gunakan adalah mengacu kepada sistem versi sebelumnya yang telah diimplementasikan pada salah satu lokasi lalu lintas, yaitu di Jalan Soekarno-Hatta Bandung. Peta lalu lintas untuk Jalan Soekarno-Hatta ditunjukkan pada Gambar 2.

Berdasarkan rancangan simulasi pada Gambar 2, sistem LINTAS dibangun untuk simulasi lalu lintas pada satu area tertentu di kota Bandung. Pada artikel ini, diambil area lalu lintas satu arah jalan Gatot Subroto dari arah perempatan jalan Pelajar Pejuang menuju perempatan jalan Ibrahim Adjie.

LINTAS akan diujicobakan pada lokasi

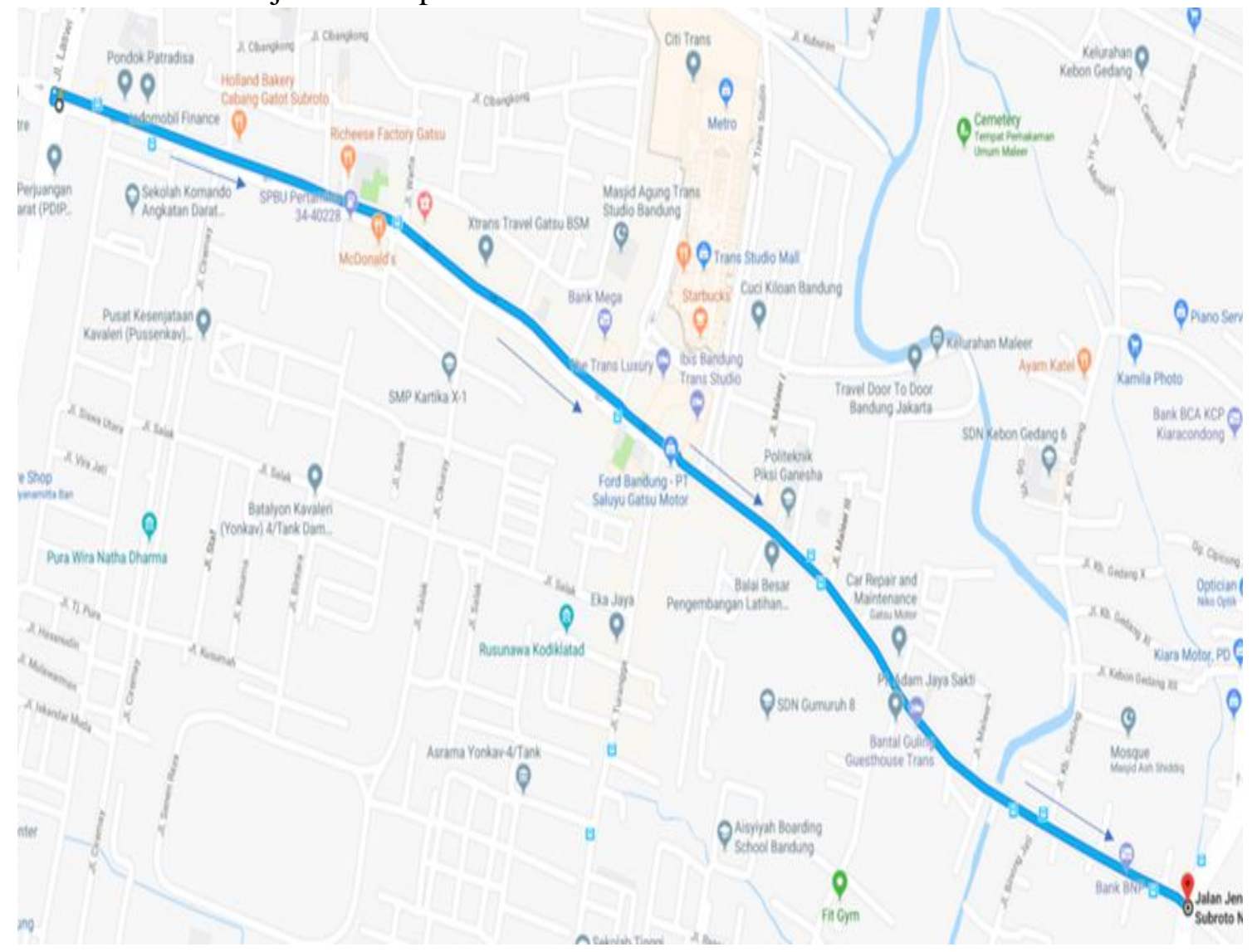

Gambar 2. Peta Jalan Gatot Subroto Bandung 
Selanjutnya disusun sistem simulasi LINTAS dengan menggunakan lima modul utama yaitu paket data generator (entity generator) sebagai pembangkit jumlah kendaraan, modul antrian (entity queue), modul server (entity server) sebagai modul proses/pelayanan, modul terminator untuk menghapus paket data yang sudah digunakan, serta link sebagai ruas jalan. Hasil update sistem LINTAS adalah ditunjukkan pada Gambar 3.

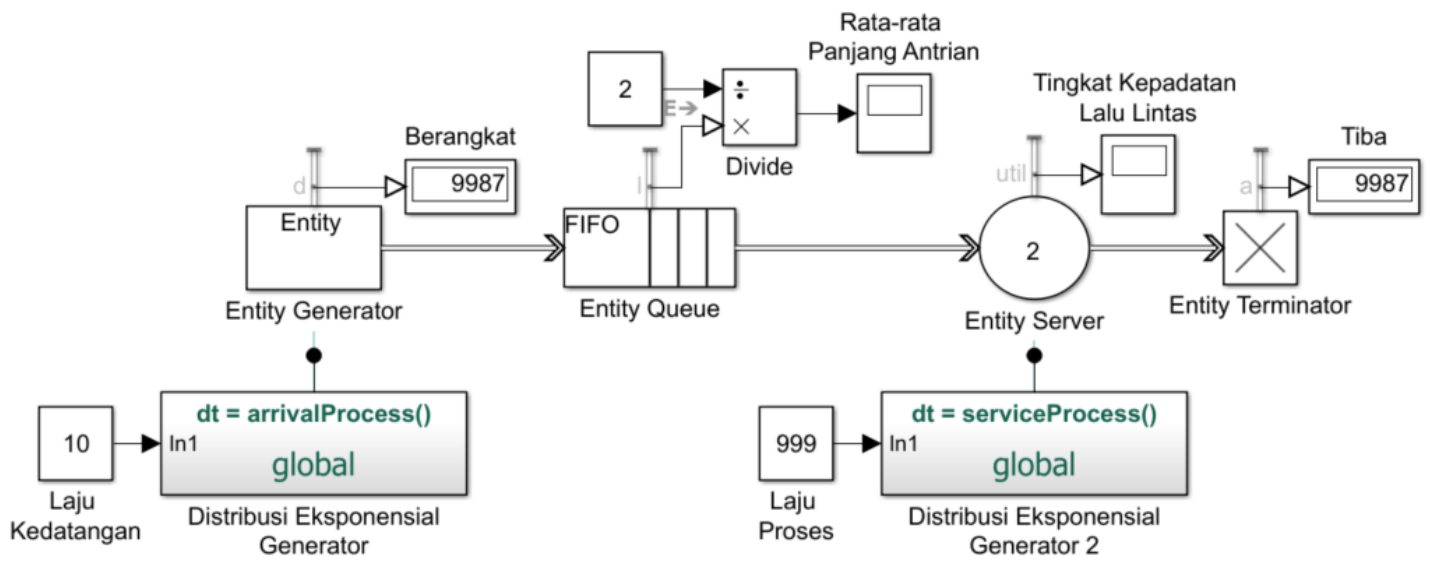

Gambar 3. Sistem LINTAS untuk jalan Gatot Subroto

Sebagaimana disampaikan pada bagian kedua bahwa model antrian pada sistem LINTAS diasumsikan sebagai $\mathrm{M} / \mathrm{M} / \mathrm{n}$, maka laju kedatangan bersifat Poisson dengan pola kedatangan secara acak mengikuti distribusi exponensial.
Begitu pula untuk laju proses atau layanan kendaraan. Dengan demikian, blok generator dan server harus di setup terlebih dahulu sebagaimana ditunjukkan pada Gambar 4.

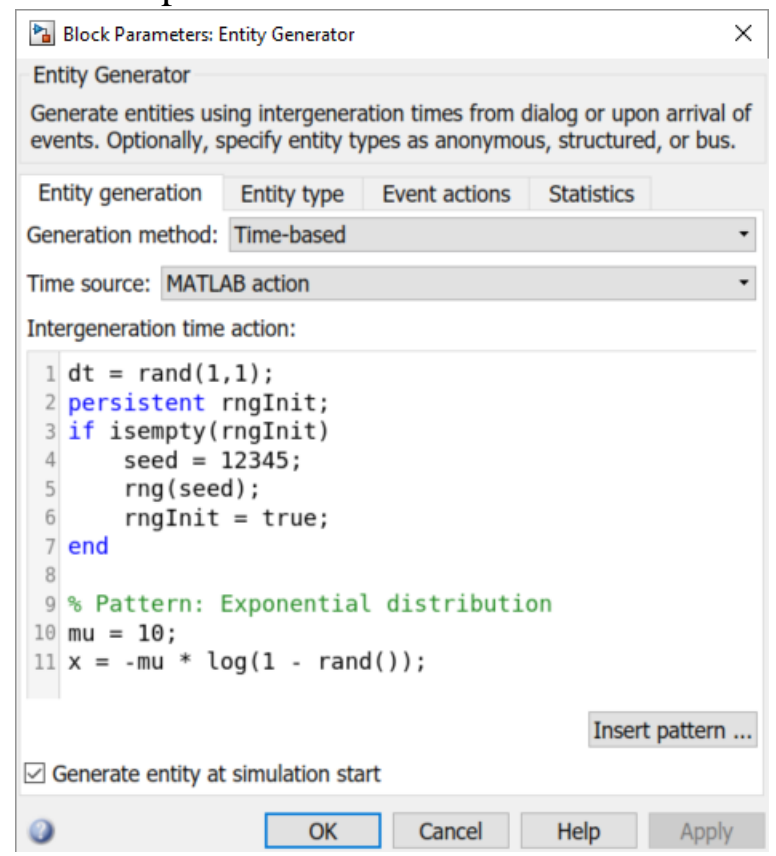

Gambar 4. Parameter untuk modul Entity Generator 
Setting entity generator dapat diinputkan adalah rata-rata kedatangan juga menggunakan modul eksternal kendaraan. sebagaimana ditunjukkan pada Gambar 5. Input data untuk laju kedatangan diinputkan secara manual. Nilai $(\lambda)$ yang

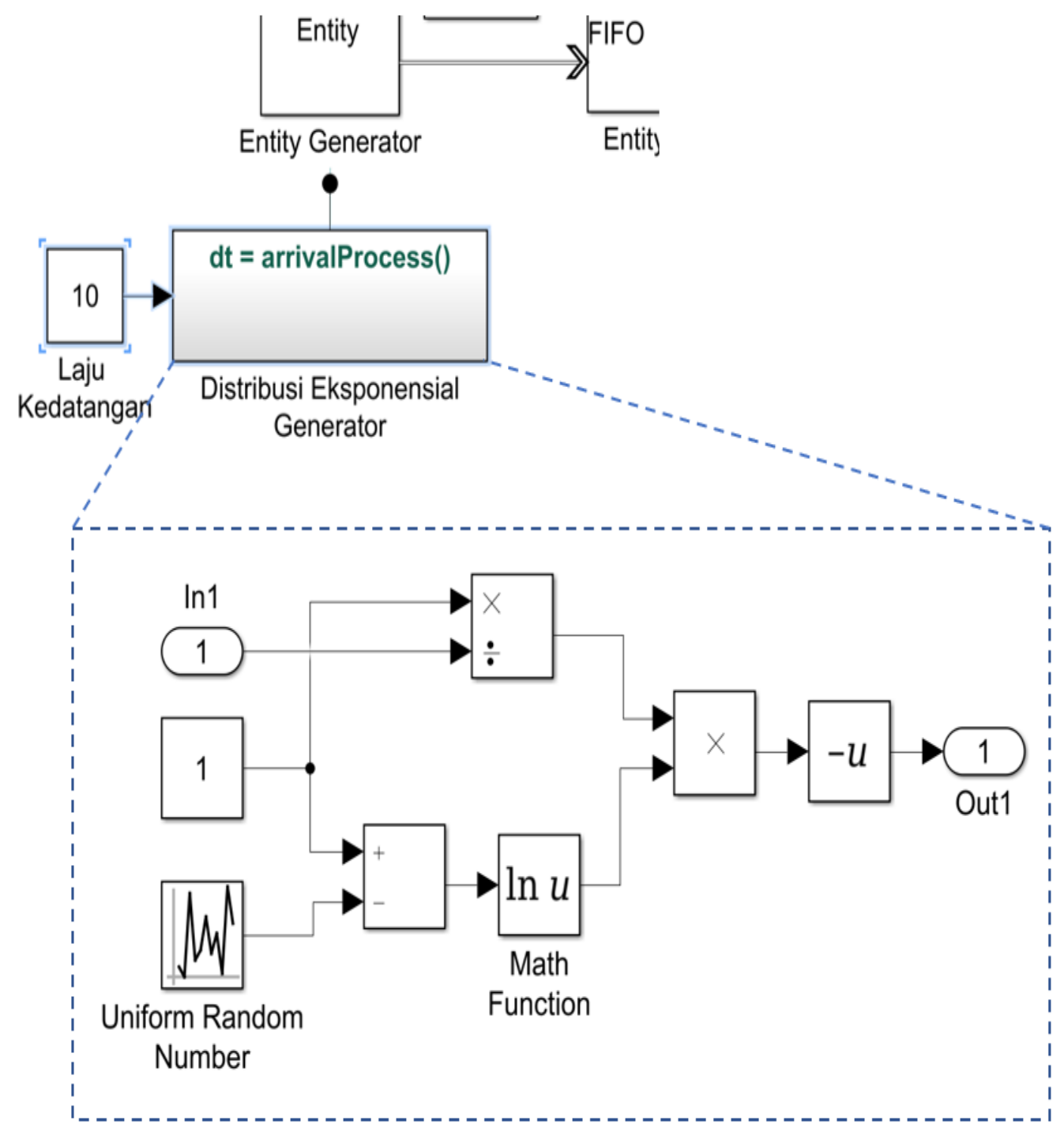

Gambar 5. Input data mengikuti distribusi eksponensial untuk Entity Generator

Nilai tersebut selanjutnya digenerate mengikuti distribusi eksponensial. Langkah ini juga diterapkan untuk input rata-rata proses/layanan kendaraan $(\mu)$ mengikuti distribusi eksponensial pada modul server. Parameter $\lambda$ dan $\mu$ memiliki satuan jumlah kendaraan per detik, dengan batasan nilai adalah $0<(\lambda, \mu)<$ $\infty$.
Tahap selanjutnya adalah menjalankan simulasi. Dalam implementasi ini diujicobakan beberapa parameter generator dan server sebagaimana ditunjukkan pada Tabel 1 . 
Tabel 1 Setting Parameter $\mu$

\begin{tabular}{|c|l|l|}
\hline ke Simulasi & Generator & Server \\
\hline 1 & 10 & Tak Hingga \\
\hline 2 & 2 & 1 \\
\hline 3 & 100 & 50 \\
\hline 4 & 20 & 20 \\
\hline
\end{tabular}

Durasi waktu simulasi ditentukan selama 1000 detik. Jumlah server $(n)$ adalah 1. Hasil dari simulasi yang akan dianalisis adalah kemungkinan terjadinya kemacetan berdasarkan pada panjang antrian.
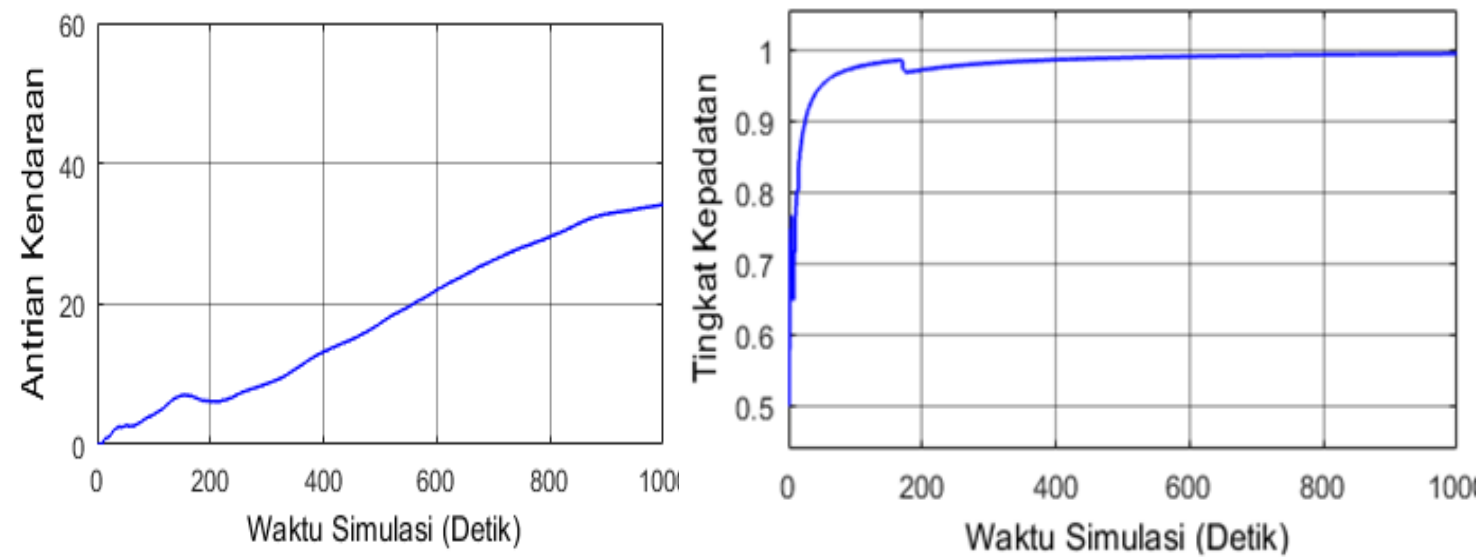

Gambar 6. Hasil Simulasi Data ke 2 pada Tabel 3.3

\section{Hasil dan Pembahasan Cakupan Wilayah Simulasi}

Cakupan wilayah pada LINTAS

1.1 lebih diperluas dibandingkan dengan versi sebelumnya, dengan titik sentral Universitas Islam Bandung, yang mencakup radius hingga $1.3 \mathrm{Km}$ dengan 26 titik fokus analisis yang ditunjukkan pada Gambar 7. Pada tiap-tiap titik,

\section{Preview Hasil Simulasi}

Sebagai contoh, simulasi dengan sistem LINTAS dijalankan berdasarkan parameter pada Tabel 1. Hasil untuk simulasi Kedua ditunjukkan pada Gambar 6.

dilakukan analisis terhadap beberapa komponen lalu lintas diantaranya adalah kedatangan kendaraan, hambatanhambatan, durasi lampu lalu lintas, danlain-lain. Selanjutnya komponenkomponen lalu lintas tersebut digunakan sebagai data input untuk menjalankan simulasi. 


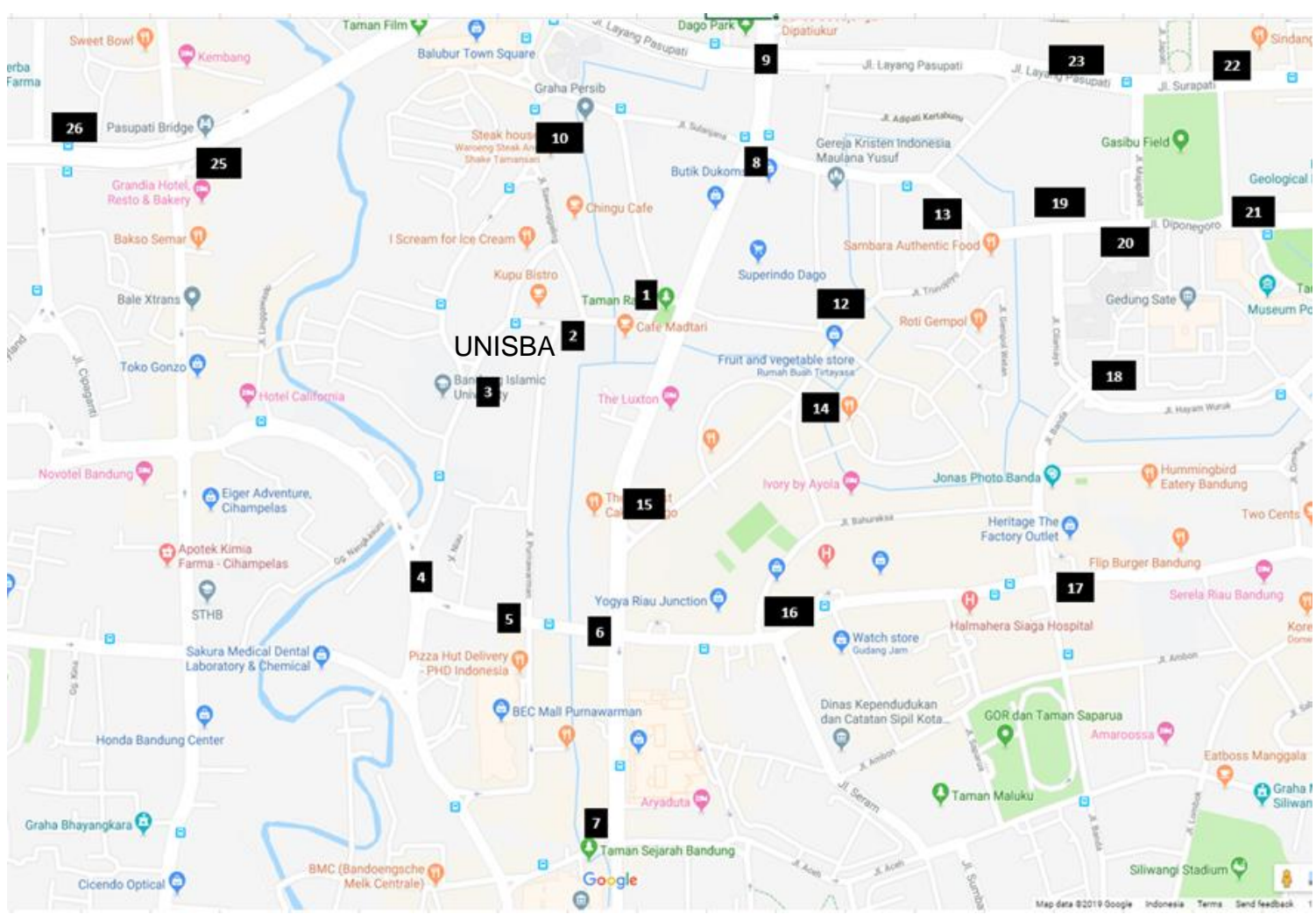

Gambar 7. Ruang lingkup wilayah simulasi lalu lintas

Selanjutnya berdasarkan pada gambar 1, disusun sistem LINTAS 1.1 menggunakan aplikasi SimEvents MATLAB-Simulink dengan mengacu kepada sistem versi sebelumnya [Piksi
Ganesha, Jurnal Matematika 17-1, ICST, Jurnal Matematika 17-2]. Tampilan dari sistem LINTAS 1.1 ditunjukkan pada Gambar 8.
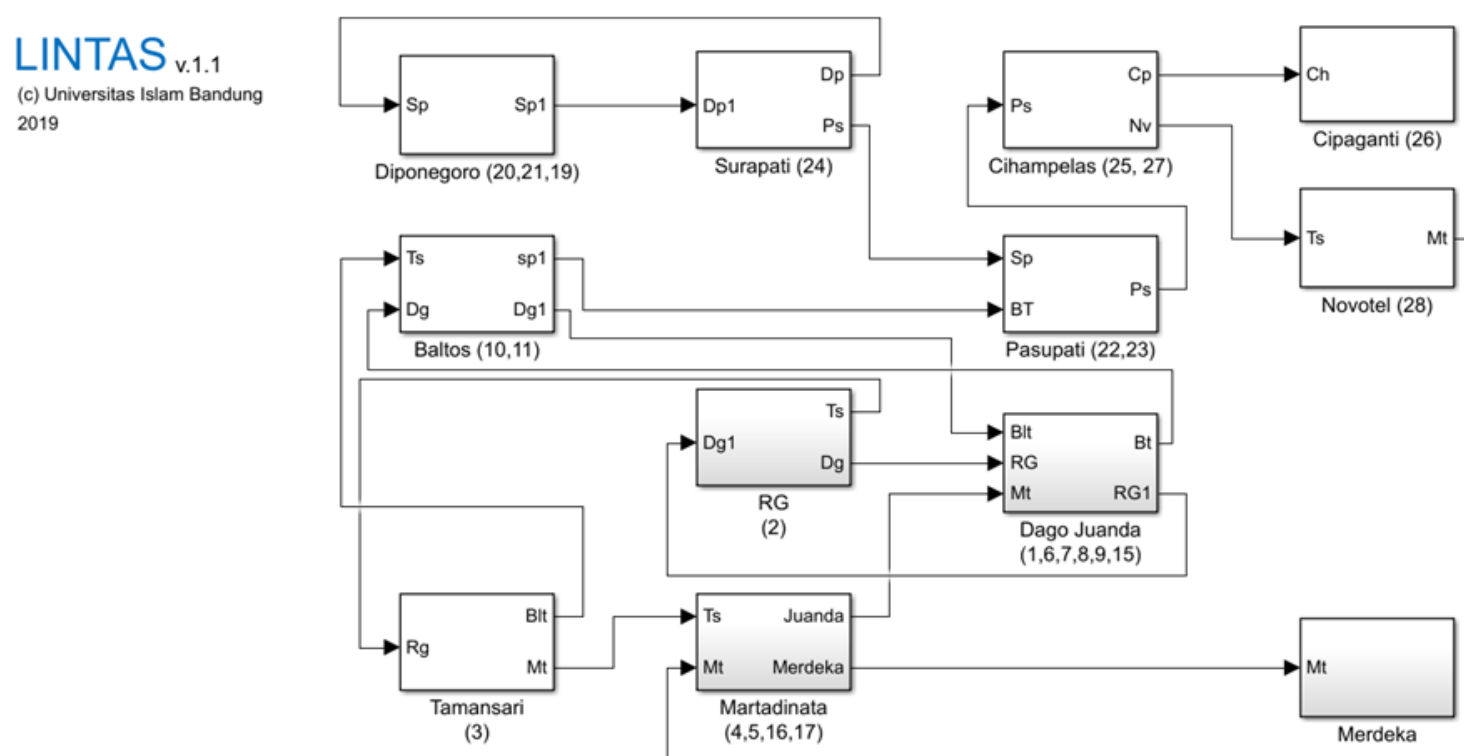

(3)

Gambar 8. Tampilan Sistem LINTAS 1.1 


\section{Kesimpulan}

Berdasarkan hasil dari simulasi, dapat disimpulkan bahwa metode load balancing memberikan solusi yang cukup signifikan dalam mengurangi panjang antrian lalu lintas. Antrian lalu lintas berkurang menunjukkan bahwa kemacetan lalu lintas dapat dihindari, sehingga waktu perjalanan dari satu tempat ke tempat lain dapat ditempuh secara normal. Semoga metode ini dapat dijadikan sebagai metode alternatif dalam mengurangi kemacetan lalu lintas.

Sebagai saran untuk penelitian lebih lanjut, perlu dikembangkan mengenai alternatif jalur disamping jalur utama yang selama ini dipergunakan, khususnya oleh warga Bandung, mengenai kualitas jalan sehingga layak untuk digunakan sebagai jalur alternatif. Juga dapat diterapkan jenis algoritma lainnya dari metode load balancing untuk memperoleh hasil yang lebih baik dari algoritma Round Robin dan Random.

\section{Daftar Pustaka}

Ariyanti. (2017) . Ini Sebab Macet Masih Terjadi Meski Jalan Tol Bertambah 176 Km. Liputan 6, 21 Maret 2017. [Online]. Available: http://bisnis.liputan6.com. [Diakses 3 Maret 2018].

Prakasa. (2017) .Jadi Biang Macet, Terminal Legendaris di Bandung Bakal Dibongkar. Liputan 6, 18 Oktober 2017. [Online]. Available: http://regional.liputan6.com. [Diakses 27 Februari 2018].

H. A. Halim. (2017). Tiga Usulan Pemkab Bogor Kurangi Beban di Jalur Puncak," 3 Mei 2017. [Online]. Available: http://www.pikiran- rakyat.com. [Diakses 26 Februari 2017].

S. Ravel. (2018). Kemacetan Liburan, Rekayasa Lalu Lintas Tak Efektif," 2 Januari 2016. [Online]. Available: http://sains.kompas.com. [Diakses 27 Februari 2018].

E. A. Retaduari. (2018). Ini Aneka Penyebab Macet Parah di Jakarta Senin Pagi Ini. Detik News, 12 Juni 2017. [Online]. Available: https://news.detik.com. [Diakses 27 Februari 2018].

T. Rachman. (2015). Kerugian Akibat Macet di Jakarta Capai Rp 65 Triliun per Tahun. REPUBLIKA, 15 Mei 2015. [Online]. Available: http://nasional.republika.co.id. [Diakses 27 Februari 2018].

A. Agustina. (2017). Atasi macet, Pemkot Bandung akan perbanyak bus. Merdeka.com, 5 Januari 2017. [Online]. Available: https://bandung.merdeka.com. [Diakses 27 Februari 2018].

T. Ispranoto. (2018). Ridwan KamilOded Belum Optimal Selesaikan Macet dan Banjir," Detik News, 11 Desember 2017. [Online]. Available: https://news.detik.com. [Diakses 27 Februari 2018].

Gunter Bolch, Stefan Greiner, Hermann de Meer, Kishor S. Trivedi, (2006). Queueing Networks and Markov Chains 2nd, New Jersey, USA.: John Wiley \& Sons, Inc.

E. Harahap, J. Wijekoon, R. Tennekoon, F. Yamaguchi, S. Ishida dan $\mathrm{H}$. Nishi, (2013) "Modeling of Routerbased Request Redirection for Content Distribution Network," International Journal of Computer Applications (IJCA), vol. 76, no. 13, pp. 37-46.

https://doi.org/10.29313/ethos.v7i2.4541 
E. Harahap, I. Sukarsih, H. Farid dan M. Y. Fajar, (2017). "Model Antrian Dengan Pengalihan Dinamis untuk Mengurangi Kemacetan Jalan Raya," ETHOS (Jurnal Penelitian dan Pengabdian), vol. 5, no. 2, pp. 182185,

M. R. Fadhillah, I. Sukarsih dan E. Harahap, (2017). "Simulasi Pengaturan Lampu Lalu Lintas Menggunakan Fuzzy Inference System Metode Mamdani pada MATLAB," 2017.

E. Harahap, I. Sukarsih, G. Gunawan, M. Y. Fajar, D. Darmawan dan H. Nishi. (2016).“A Model-Based Simulator for Content Delivery Network using SimEvents MATLAB-Simulink,"
INSIST: International Series on Interdisciplinary Science and Technology, vol. 1, no. 1, pp. 30-33, J Wijekoon, R Tennekoon, E Harahap, H Nishi, (2014). service-oriented router module implementation on ns3," dalam SIMUTOOLS 2014: The 7th International ICST Conference on Simulation Tools and Techniques.

E. Harahap, W. Sakamoto dan H. Nishi, (2010). Failure prediction method for network management system by using Bayesian network and shared database," dalam Information and Telecommunication Technologies (APSITT), 2010 8th Asia-Pacific Symposium on, Kota Kinabalu, Malaysia.. 